\title{
A JUSTICIALIDADE DAS POLÍTICAS PÚBLICAS DE SAÚDE DO IDOSO
}

\section{Paulo Márcio Cruz ${ }^{1}$}

Zenildo Bodnar ${ }^{2}$

Roberta Terezinha Uvo Bodnar ${ }^{3}$

\section{Resumo}

O artigo tem por objeto a justicialidade das políticas públicas de saúde do idoso. Parte da análise do principal responsável pela gestão e pela implementação de políticas públicas de saúde; detalha a situação da saúde do idoso e examina o atual posicionamento dos Tribunais Superiores quanto ao reconhecimento da sua legitimidade para atuar nas políticas públicas de saúde, especialmente nos casos que envolvem o direito à saúde do idoso. A pesquisa recorre ao método de abordagem indutiva, por meio das seguintes técnicas de pesquisa: bibliográfica, documental, legal, e, especialmente, por meio da técnica jurisprudencial - utilização de livros e revistas especializados.

Palavras-chave: Justicialidade; Políticas públicas; Direito à saúde; Idoso.

\section{INTRODUÇÃO}

O presente artigo tem como objetivo analisar a justicialidade das políticas públicas de saúde do idoso ofertada, processada e julgada perante os Tribunais Superiores. O marco teórico desta pesquisa está centrado na avaliação dos Direitos Fundamentais, com destaque aos autores Dworkin e Sarlet, bem como no aparato institucional atualmente voltado à concretização das Políticas Públicas com destaque no Poder Judiciário.

Parte-se da premissa que, com a alteração no perfil populacional, caracterizado principalmente pelo aumento progressivo no número de idosos, conforme os dados do Instituto Brasileiro de Geografia e Estatísticas $(\mathrm{IBGE})^{4}$, surge maior preocupação e maiores desafios com o quadro populacional que ora se apresenta,

\footnotetext{
${ }^{1}$ Pós-Doutorado em Direito do Estado pela Universidade de Alicante - Espanha. Coordenador e professor no Programa de PósGraduação Stricto Sensu em Ciência Jurídica da Universidade do Vale do Itajaí (Univali) em seus programas de Doutorado e Mestrado em Ciência Jurídica. Professor-visitante nas Universidades de Alicante - na Espanha, e de Perugia - na Itália. E-mail: pcruz@univali.br

2 Pós-Doutorado em Direito Ambiental na Universidade Federal de Santa Catarina e Pós-Doutorado em Direito Ambiental na Universidade de Alicante (Espanha). Professor dos Programas de Doutorado e Mestrado na Universidade do Vale do Itajaí (SC) UNIVALI (SC, Brasil).E-mail: zenildo@univali.br

${ }^{3}$ Mestre em Direito pela Universidade Federal de Santa Catarina (UFSC). Professora da Especialização em Direito Previdenciário e do Trabalho na Universidade do Vale do Itajaí (UNIVALI).E-mail: roberta_uvo@univali.br

${ }^{4}$ Para comprovar a perspectiva do aumento progressivo do número de idosos no Brasil, com a consequente mudança no perfil populacional, deve-se observar as pesquisas e os dados realizados pelo Instituto Brasileiro de Geografia e Estatística - IBGE, tais
} 
especialmente quando o desafio reside na (re)afirmação do direito do idoso à saúde. É importante lembrar que há grande quantidade de pessoas com idade igual ou superior a sessenta e cinco anos de idade que já se encontram excluídas de um sistema efetivo e integral de proteção e defesa.

Nos termos da Constituição da República Federativa do Brasil de 1988, ao Poder Público cumpre a gestão e a implementação de políticas públicas de saúde que materializem o direito à saúde, já que, no ordenamento jurídico, tal direito já foi devidamente declarado e reconhecido pelo Constituinte. Embora reconhecido, a prestação desse direito não corresponde ao que está legalmente previsto, o que tem gerado a justicialização da saúde devido à gestão pública deficiente; afinal, ao Poder Judiciário também é destinado este dever, conforme será exposto neste artigo.

\section{GESTÃO E IMPLEMENTAÇÃO DE POLÍTICAS PÚBLICAS DE SAÚDE}

As políticas públicas passam a ter importância a partir do momento em que o Estado assume a responsabilidade de proporcionar o bem-estar social. Para tanto, o Estado institui diretrizes com a finalidade de garantir a concretização de direitos sociais fundamentais que dependem da intervenção estatal, especialmente do direito à saúde, o qual integra o objeto do presente estudo.

Dworkin (2002, p. 36), ao traçar um conceito operacional sobre política, assim estabelece:

Denomino 'política' aquele tipo padrão que estabelece um objetivo a ser alcançado, em geral uma melhoria em algum aspecto econômico, político ou social da comunidade (ainda que certos objetivos sejam negativos pelo fato de estipularem que algum estado atual deve ser protegido contra mudanças adversas).

Em se tratando de políticas públicas, Freire Júnior (2005, p. 47) afirma que esta expressão - políticas públicas - "pretende significar um conjunto ou uma medida isolada praticada pelo Estado com o desiderato de dar efetividade aos direitos fundamentais ou ao Estado Democrático de Direito". Já Souza (2006, p. 7) conceitua que as políticas públicas são "o campo do conhecimento que busca, ao mesmo tempo, 'colocar o governo em ação’ e/ou analisar essa ação (variável independente) e, quando necessário, propor mudanças no rumo ou curso dessas ações (variável dependente)".

Sobre o conceito de política pública, no sentido de programa de ação, Comparato (1998, p. 44) explica que:

[...] só recentemente passou a fazer parte das cogitações da teoria jurídica. E a razão é simples: ele corresponde a uma realidade inexistente ou desimportante antes da Revolução Industrial, durante todo o longo período histórico em que se forjou o conjunto dos conceitos jurídicos

como a Projeção da população do Brasil 2000/2060, por sexo e idade, e a Síntese de Indicadores Sociais - uma análise das condições de vida da população brasileira, do ano de 2014, disponíveis, respectivamente, em: <http://www.ibge.gov.br/home/presidencia/noticias/imprensa/ppts/00000014425608112013563329137649.pdf> e <ftp://ftp.ibge.gov.br/Indicadores_Sociais/Sintese_de_Indicadores_Sociais_2014/SIS_2014.pdf>. Acessos em: 6 fev. 2017 e 8 fev. 2017. 
dos quais nos servimos habitualmente.

Acrescenta, ainda, o referido autor (1998, p. 45) que "a política aparece, antes de tudo, como uma atividade, isto é, um conjunto organizado de normas e atos tendentes à realização de um objetivo determinado".

No estudo do ciclo das políticas públicas três etapas são fundamentais: a) formulação; b) execução; c) controle. A formulação de políticas públicas se refere ao processo de gerar um conjunto de escollhas de politicas plausíveis para resolver problemas. (WU, XUN, et all, 2014, p. 52). O enfoque desta pesquisa estará concentrado no controle, especificamente o judicial e para sua compreensão a análise do seu conceito jurídico é essencial.

Ao tratar do conceito jurídico de políticas públicas, Bucci (2006, p. 31) reconhece que este não é uma categoria definida pelo direito, mas arranjos complexos típicos da atividade político-administrativa, que a ciência do direito deve estar apta a descrever, compreender e analisar, de modo a integrar à atividade política os valores e métodos próprios do universo jurídico, numa perspectiva que realça também o caráter interdisciplinar da análise.

A referida autora (2006, p. 39) descreve o conceito de política pública em Direito da seguinte maneira:

Política pública é o programa de ação governamental que resulta de um processo ou conjunto de processos juridicamente regulados - processo eleitoral, processo de planejamento, processo de governo, processo orçamentário, processo legislativo, processo administrativo, processo judicial - visando coordenar os meios à disposição do Estado e as atividades privadas, para a realização de objetivos socialmente relevantes e politicamente determinados. Como tipo ideal, política pública deve visar a realização de objetivos definidos, expressando a seleção de prioridades, a reserva de meios necessários à sua consecução e o intervalo de tempo em que se espera o atingimento dos resultados.

Por fim, quanto ao conceito de políticas públicas, Freitas (2014, p. 146) explica que são autênticos programas de Estado que buscam articular diversos atores governamentais e sociais na busca da concretização dos direitos fundamentais das presentes e futuras gerações.

Para além da perspectiva teórica das políticas públicas, importante também deixar registrado que na perspectiva da Ciência das Políticas Públicas estas se caracterizam como ciclo, composto por várias etapas e com diversos processos que mutuamente interagem e sofrem influências, sendo vários os atores protagonistas (WU, XUN ett all. 2014). Esta perspectiva de análise é fundamental para a tomada de decisões estratégicas por parte dos Gestores Públicos a partir de uma visão holística e sistêmica.

Defende Freitas (2014, p. 148) que as políticas públicas não podem ser consideradas meros programas governamentais e apresenta os elementos caracterizadores das políticas públicas, quais sejam: (a) são programas de Estado Constitucional (mais do que de governo), que reclamam motivada formulação entre alternativas constitucionalmente defensáveis, (b) processados por atos de cognição e de vontade dos múltiplos atores políticos, no intuito de solver problemas sociais concretos, e que (c) devem consubstanciar, na prática governamental, prioridades cogentes, geradoras de benefícios excedentes aos custos diretos e indiretos.

Já que o enfoque deste estudo é o direito fundamental à saúde, como já descrito no item 1.1, é importante realçar que este direito é considerado de segunda dimensão, apesar de consagrado pela Constituição 
da República Federativa do Brasil de 1988, em seu artigo 6º Considera-se o direito à saúde um direito de segunda dimensão devido ao fato de que a saúde decorre do dever de o Estado garantir o direito à vida e à dignidade da pessoa humana. Ora, o que se torna necessário concluir é que não há possibilidade de o ser humano exercer suas atividades cotidianas com qualidade quando o direito à saúde não é plenamente efetivado, seja através de atendimento médico-hospitalar, seja através da providência de medicamentos ou de outros procedimentos, ou seja, o direito à vida fica comprometido se não for garantido o efetivo direito à saúde.

Além disso, a própria Constituição da República Federativa do Brasil de 1988, como observado no item acima, estabelece, em seu artigo 196, que a saúde é direito de todos e dever do Estado, o que é "garantido mediante políticas sociais e econômicas que visem à redução do risco de doença e de outros agravos e ao acesso universal e igualitário às ações e serviços para sua promoção, proteção e recuperação" (BRASIL, 1998).

Desse dever imposto pela Constituição da República Federativa do Brasil de 1988, surge também a responsabilização do Estado, constante no artigo $37, \$ 6^{\circ}$, da referida Constituição, conforme se depreende do seguinte julgado:

ADMINISTRATIVO. SAÚDE. SUS. CIRURGIA. EXISTÊNCIA DE POLÍTICA PÚBLICA. DEMORA INJUSTIFICADA NA PRESTAÇÃO. DANOS MORAIS. CABIMENTO. 1. Para fazer jus à cirurgia paga por entes políticos, deve a parte autora comprovar a sua atual necessidade e ser aquele procedimento requerido insubstituível por outro qualquer tratamento no caso concreto. 2. Demonstrada a falha no atendimento prestado no âmbito no SUS pela demora injustificada na realização de cirurgia, passados mais de três anos da primeira consulta, resta caracterizada a responsabilidade civil e o dever de indenizar pelo dano moral sofrido. (TRF4, AC 5000378-68.2010.404.7210, Quarta Turma, Relator p/ Acórdão Luís Alberto D'azevedo Aurvalle, D.E. 16/11/2012)

Logo, furtando-se o Estado de seu dever de proteger e de defender o direito fundamental à saúde, poderá ser responsabilizado por sua conduta e deverá indenizar o demandante pelo dano sofrido.

Dessa forma, incumbe ao Poder Público, a gestão e implementação de políticas públicas de saúde para fins de materializar este direito no plano fático, eis que no ordenamento jurídico tal direito já foi devidamente declarado e reconhecido pelo Constituinte. Nesse sentido, Bodnar (2013, p. 302) explica que apesar dos avanços no plano legislativo, muitos desafios ainda são constatados na implementação prática do direito à saúde. Pois os serviços de saúde que são disponibilizados concretamente para a população, especialmente para os mais fragilizados socialmente, não correspondem à pauta ambiciosa e generosa prevista pelo Constituinte. Esse fato, aliado à falta de articulação adequada entre os entes públicos responsáveis pela implementação das políticas sanitárias, gera uma significativa judicialização do tema, circunstância essa que torna os juízes também partícipes da gestão do sistema público de saúde, considerando o elevado potencial de impacto econômico das suas decisões.

Assim também escreve Krell (2002, p. 31-32), afirmando que a grande maioria das normas sociais já existem, porém, "o problema certamente está na formulação, implementação e manutenção das respectivas 
políticas públicas e na composição dos gastos nos orçamentos da União, dos estados e dos municípios". Isso porque os Poderes Legislativo e Executivo não têm atuado efetivamente no que se refere à concretização das políticas públicas de saúde, muitas vezes deixando de pôr em prática aquilo que já está determinado no plano normativo.

Dentre os principais fundamentos utilizados pelos referidos Poderes Públicos para absterem-se de consolidar o direito à saúde através da gestão e implementação de políticas públicas são a "reserva do possível" e a escassez de recursos financeiros. Mas há também a interpretação errônea deste direito social fundamental no sentido de restringir a sua integralidade 5 .

Tais fundamentos não podem ser opostos diante da força constitucional que possui o direito social fundamental à saúde ${ }^{6}$. Este direito deve ser conferido a todos os indivíduos de uma sociedade, seja em benefício da coletividade - tal como ocorre quando da construção de hospitais públicos, do investimento em equipamentos médicos avançados dentre outras ações - seja em benefício individual, nos casos, por exemplo, em que um único indivíduo pleiteia a concessão de medicamento indispensável à sua própria vida.

A integralidade do direito à saúde é um relevante preceito a ser observado pelos Poderes Públicos na atuação em prol deste direito. Neste sentido, importante descrever o entendimento de Aith (2007, p. 397-398):

[...] a diretriz de integralidade das ações e serviços públicos de saúde representa um importante instrumento de defesa do cidadão contra eventuais omissões do Estado, pois este é obrigado a oferecer, prioritariamente, o acesso às atividades preventivas de proteção da saúde. A prevenção é fundamental para evitar a doença, entretanto, sempre que esta acometer um cidadão, compete ao Estado oferecer o atendimento integral, ou seja, todos os cuidados de saúde cabíveis para cada tipo de doença, dentro do estágio de avanço do conhecimento científico existente. Assim, sempre que houver uma pessoa doente, caberá ao Estado fornecer o tratamento terapêutico para a recuperação da saúde dessa pessoa de acordo com as possibilidades oferecidas pelo desenvolvimento científico. Assim, não importa o nível de complexidade exigido, a diretriz de atendimento integral obriga o Estado a fornecer todos os recursos que estiverem ao seu alcance para a recuperação da saúde de uma pessoa, desde o atendimento ambulatorial até os transplantes mais complexos. Todos os procedimentos terapêuticos reconhecidos pela ciência e autorizados pelas autoridades sanitárias competentes devem ser disponibilizados para a proteção da saúde da população.

Ainda sobre a integralidade do direito à saúde, Marques (2009, p. 20) ressalta que a ameaça de restringir a aplicação de um princípio constitucional à política pública prevista "pode representar um retrocesso em relação à garantia do direito à saúde, nos moldes em que foi concebido pela Constituição Federal de 1988 e pela tão sonhada reforma sanitária no Brasil”.

Destaca-se que, ao se manter inerte diante da devida formulação e execução de políticas públicas de

\footnotetext{
${ }^{5}$ Ver Projeto de Lei do Senado n. 219/07. Apesar de ter sido rejeitado o projeto demonstra uma vertente contrária à integralidade e universalidade do direito à saúde. BRASIL. Senado Federal. Projeto de Lei no 219, de 2007. Disponível em: <http://www.senado.gov.br/atividade/materia/getPDF.asp?t=51228\&tp=1>. Acesso em: 27 jan. 2017.

${ }^{6}$ Nesse sentido, Krell (2002, p. 23) afirma que: "A negação de qualquer tipo de obrigação a ser cumprida na base dos Direitos Fundamentais Sociais tem como consequência a renúncia de reconhecê-los como verdadeiros direitos”.
} 
saúde, o Poder Público estará infringindo o princípio da proibição do retrocesso. Segundo Bodnar (2013, p. 303), este princípio "representa a seta que sinaliza, orienta e impulsiona os governantes e agentes públicos, inclusive juízes, na busca contínua pela ampliação de espaços de cidadania mediante a concretização dos direitos fundamentais".

O Poder Executivo e o Poder Legislativo, a quem em princípio seria incumbido o dever de gestão e implementação de políticas públicas para a efetivação de direitos sociais fundamentais como a saúde, não têm atendido aos anseios pelos quais lhes fora atribuída esta legitimidade e competência. Sendo assim, Cunha Júnior (2010, p. 629) alerta que:

Em caso descumprimento, por omissão, de algum direito fundamental ou de lacuna legislativa impeditiva de sua fruição, deve e pode o Judiciário -valendo-se de um autêntico dever-poder de controle das omissões do poder público - desde logo e em processo de qualquer natureza, aplicar diretamente o preceito definidor do direito em questão, emprestando ao direito fundamental desfrute imediato, independentemente de qualquer providência de natureza legislativa ou administrativa.

Nesse contexto, Krell (2002, p. 22-23) destaca a margem de substancial autonomia do legislador para definir o direito social a ser assegurado ao enfatizar a abertura das normas para acolher diversas concretizaçôes consoante as alternativas periodicamente escolhidas pelo eleitorado. Essa abertura é necessária inclusive para que sejam considerados os meios necessários para a efetivação. Assim, em princípio, o Poder Judiciário não deve intervir em esfera reservada a outro Poder para substituí-lo, mas apenas excepcionalmente, quando haja uma violação evidente arbitrária, pelo legislador, da incumbência constitucional.

Por fim, Sarlet (2007, p. 13) conclui que se deve reconhecer um direito subjetivo do particular à prestação reclamada em Juízo, pois:

Tal argumento cresce em relevância em se tendo em conta que a nossa ordem constitucional (acertadamente, diga-se de passagem) veda expressamente a pena de morte, a tortura e a imposição de penas desumanas e degradantes mesmo aos condenados por crime hediondo, razão pela qual não se poderá sustentar - pena de ofensa aos mais elementares requisitos da razoabilidade e do próprio senso de justiça - que, com base numa alegada (e mesmo comprovada) insuficiência de recursos - se acabe virtualmente condenando à morte a pessoa cujo único crime foi o de ser vítima de um dano à saúde e não ter condições de arcar com o custo do tratamento.

Portanto, quando o Estado é omisso ${ }^{7}$ o Poder Judiciário assume uma importante missão na realização do controle de políticas públicas de saúde, uma vez que por intermédio de suas decisões judiciais, na qualidade de guardião dos direitos e garantias fundamentais, tem possibilitado que o direito à saúde não permaneça apenas como uma "letra morta na lei". À medida que este estudo avançar, será indicado que o controle das políticas públicas de saúde também se apresenta como missão, inclusive, dos Tribunais Superiores: Supremo Tribunal

\footnotetext{
${ }^{7}$ Quanto à omissão do Poder Público, Freitas (2014, p. 154) assim exemplifica: "a omissão traduz-se como descumprimento, doloso ou culposo, das diligências mandatórias, relacionadas, por exemplo, aos deveres $[\ldots]$ de fornecer remédios à população carente ou, ainda, de cuidar apropriadamente dos idosos".
} 
Federal e Superior Tribunal de Justiça.

\section{PROTEÇÃO, PROMOÇÃO, RECUPERAÇÃO E DEFESA DA SAÚDE DO IDOSO}

No Brasil é considerada idosa, a pessoa com idade igual ou superior a sessenta anos, nos termos do Estatuto do Idoso (BRASIL, 2015). Mesmo critério adotado pela Organização das Nações Unidas (ONU), que considera idosa a pessoa com idade igual ou superior a 60 anos (ONU, 2015).

Todavia, para a Organização Mundial de Saúde (OMS), em países desenvolvidos, aos 65 anos a pessoa é considerada idosa. Já para os países em desenvolvimento, há variação neste critério. Na África, por exemplo, com 50 (cinquenta) anos a pessoa é vista idosa (OMS, 2015).

Ao tratar sobre os termos classificatórios do idoso, Peixoto $(2007 \text {, p. } 72-73 / 77)^{8}$ concluiu que o Brasil se assemelha à França, onde os termos "velho" e "velhote", quando utilizados para designar o idoso, poderão ou não estar carregados de sentido negativo; todavia, quando empregados, reforçam "uma situação de exclusão social". Ainda segundo esta autora, a noção de "velho" é "fortemente assimilada à decadência e confundida com incapacidade para o trabalho: ser velho é pertencer à categorização emblemática dos indivíduos idosos e pobres".

Não é adequado utilizar tais termos pejorativos, negativos e desprezíveis ${ }^{9}$, uma vez que o idoso se encontra em uma fase da vida em que a velhice, para a sociedade, conforme Beauvoir (1990, p. 8-12), "aparece como uma espécie de segredo vergonhoso, do qual é indecente falar". Além disso, há a crítica subliminar de que "o velho incapaz de suprir suas necessidades representa sempre uma carga”.

Mesmo após três décadas, essas conclusões de Beauvoir (1970) persistem na atualidade e bem retratam, inclusive, a realidade no Brasil:

Apesar do avanço legal, a discussão que se tem travado na sociedade brasileira em relação ao envelhecimento de sua população tem primado por realçar o impacto e o ônus da população idosa na previdência e no setor saúde. $\mathrm{O}$ velho é visto como sinônimo de aumento dos gastos, tanto em um como em outro setor. É, inclusive, indevidamente responsabilizado pelos problemas provocados ora pela má administração pública, ora pelo uso inadequado dos escassos recursos dirigidos a ambos os setores. (SOUZA; 2002, p. 192)

Assim, na sociedade brasileira, "a imagem que se tem da velhice ainda é bastante negativa" (LOBATO, 2004, p. 12). Essa negatividade, da mesma forma, faz-se presente nas políticas públicas na área da saúde do idoso:

Também para a medicina e para a saúde pública, o envelhecimento tem se apresentado como problema. As mudanças na pirâmide populacional, que vai alargando seu ápice numa

\footnotetext{
${ }^{8}$ Clarice Peixoto é Doutora em Antropologia. Os termos classificatórios sobre o idoso também foram objeto de sua tese de Doutorado na Escola de Altos Estudos em Ciências Sociais (École des Hautes Études en Sciences Sociales -EHESS), de Paris, no ano de 1993.

${ }^{9}$ Não se desconhece a crítica de alguns autores, como a do Presidente da Academia Brasileira de Filosofia, João Ricardo Moderno, que, ao comentar em seu artigo "Ontoestética do idoso" (2004, p. 79) considerou desnecessária a escolha de eufemismo para o termo "velhice": "Velhice é uma palavra detestada pela onda politicamente correta, que prefere os eufemismos a chamar as coisas pelo nome”.
} 
média de 2,5\% de crescimento anual, geram preocupações para o sistema de saúde, porque mesmo sem ter solucionado os problemas sanitários relativos à infância, à adolescência e aos trabalhadores, ambos terão de se equipar para dar respostas eficientes relativas à prevenção de enfermidades e à atenção aos enfermos idosos. (MINAYO; COIMBRA JR., 2002, p. 17)

Contudo, cumpre registrar que este mesmo idoso, visto muitas vezes pela sociedade como um "fardo" a ser carregado, especialmente na área da saúde pública, do ponto de vista econômico, está inserido em um mercado crescente tanto de consumo, quanto da cultura, do lazer, da estética e dos serviços de saúde. Somando a isso, do ponto de vista sociológico, explicam Minayo e Coimbra Jr. (2002, p. 22), o idoso constitui um "emergente ator social, com poder de influir nos seus destinos, pela sua significância numérica e qualitativa, por meio da construção de leis de proteção, de conquista de benefícios e pela presença no cenário político”.

Todorov (2014, p. 108), filósofo búlgaro, ao tentar compreender o lugar que a sociedade ocupa no homem, refuta enfaticamente as teorias sociais e conclui que o drama da "velhice" não é precisar dos outros, mas saber que os outros não necessitam mais de você.

A ONU (2015) destaca que as pessoas tendem a valorizar e respeitar os idosos que amam ou conhecem, mas esta atitude para com os outros idoso da comunidade pode ser diferente. Em muitas sociedades tradicionais, os idosos são respeitados, porém, em outras sociedades, podem ser menos respeitados. A marginalização a que o idoso está exposto em algumas culturas pode ser estrutural ou informal. O primeiro caso pode ser exemplificado pela aplicação do critério de idade para acesso ao direito da aposentadoria. O segundo caso está relacionado à visão construída de que as pessoas mais velhas são menos produtivas e menos valiosas para um potencial empregador. Essas atitudes são exemplo de "ageism" ${ }^{10}$-estereótipos de discriminação contra indivíduos ou grupos por causa da sua idade ${ }^{11}$.

Conclui Agustini (2002, p. 34) que a velhice “ao contrário do que pensa o imaginário coletivo, não é sinônimo de doença. Inclusive porque as doenças, que são mais frequentes em idades mais avançadas, são preveníveis, diagnosticáveis e tratáveis”.

Nesse sentido, a ONU (2012), em busca de quebrar o estereótipo de que pessoas mais velhas não merecem cuidados de saúde, afirma que:

\footnotetext{
${ }^{10}$ Conceito trazido por Richard Butler, no final de 1960 e adotado pela Comissão para o Desenvolvimento Social da ONU, durante a Segunda Assembleia Mundial sobre o Envelhecimento, realizada em Madrid 2002. A Comissão assim definiu tal termo: "meio pelo qual os direitos das pessoas idosas são negados ou violados. Estereótipos negativos e o denegrir das pessoas mais velhas podem ser traduzidos numa ausência de preocupação social para com os idosos, em risco de marginalização e na negação de igualdade de oportunidades, recursos e direitos." (VIEGAS; GOMES, 2007, p 29). Usualmente é traduzido e utilizado no Brasil como "idosismo".

${ }^{11}$ No original consta: "We all generally value and respect the older people we love or know well. But our attitudes to other older people within the broader community can be different. In many traditional societies, older people are respected as "elders". However, in other societies, older women and men may be less respected. The marginalization can be structural, for example enforced retirement ages, or informal, such as older people being viewed as less energetic and less valuable to a potential employer. These attitudes are examples of "ageism" — the stereotyping of, and discrimination against, individuals or groups because of their age." (ONU, 2015)
} 
Condições tratáveis de doenças que atingem pessoas mais velhas são muitas vezes esquecidas ou descartadas por se considerar que a doença "faz parte do envelhecimento". A idade não necessariamente causa dor, e só a extrema velhice está associada à limitação da função corporal. O direito à melhor saúde possível não diminui à medida que envelhecemos: É principalmente a sociedade que define os limites de idade para o acesso a tratamentos complexos ou a reabilitação adequada e prevenção secundária da doença e incapacidade.

Não é a idade que limita a saúde e a participação de pessoas mais velhas. Pelo contrário, são os equívocos individuais e sociais, a discriminação e o abuso que previnem o envelhecimento ativo e digno. ${ }^{12}$

Com o intuito de verificar a condição da saúde do idoso brasileiro, o IBGE (2009) formulou indicadores que permitiram ratificar a informação de que a mudança no perfil demográfico e epidemiológico - mais especificamente do perfil dos idosos - acarretou o crescimento das despesas com tratamentos médico e hospitalar. Concluiu o estudo que: "o custo das internações hospitalares e o tempo médio de permanência na rede hospitalar são expressivamente mais elevados para os idosos, devido à multiplicidade e à natureza de suas patologias”.

Ainda nesse mesmo estudo, apontou o IBGE (2009) que a redução do declínio funcional entre os idosos também ocorreria:

[...] caso se incluíssem os segmentos que não têm acesso sequer a condições socioeconômicas satisfatórias, quanto mais aos equipamentos necessários para auxiliar os idosos com dificuldades funcionais. Poder-se-ia ter, nesse caso, um cenário que aponta na direção de uma população idosa mais saudável, a despeito das consequências que o processo de envelhecimento da população acarreta no que diz respeito ao aumento das doenças crônicas e à maior necessidade de atendimento de saúde daqueles que envelhecem e que vivem, cada vez mais, até idades mais avançadas.

Extraem-se das palavras da Diretora-Geral da OMS, Margaret Chan, em notícia intitulada "ONU pede saúde adequada a idosos em todo o mundo”, publicada na página oficial da Organização das Nações Unidas (2012):

[... "Não devemos deixar que o dinheiro ou a falta de acesso decida quem se mantém em forma e quem se fragiliza mais cedo. Por exemplo, controle de hipertensão, usando medicamentos extremamente acessíveis, contribui enormemente para a longevidade, mas apenas $10 \%$ dos idosos no mundo em desenvolvimento se beneficiam deste tratamento."

Impende lembrar que o sexagenário não está de fato "velho", tanto que em estudos da Antropologia, da Assistência Social e de outras áreas, há a distinção entre “os idosos jovens e os idosos velhos”, nominando respectivamente: terceira idade ${ }^{13}$ e quarta idade ${ }^{14}$ (PEIXOTO, 2007, p. 69-84; SANTA ROSA, 2004, p. 21-50) ${ }^{15}$.

\footnotetext{
${ }^{12}$ No original consta: "Stereotype 5: Older people don't deserve health care Treatable conditions and illnesses in older people are often overlooked or dismissed as being a "normal part of ageing". Age does not necessarily cause pain, and only extreme old age is associated with limitation of bodily function. The right to the best possible health does not diminish as we age: It is mainly society that sets age limits for access to complex treatments or proper rehabilitation and secondary prevention of disease and disability. It is not age that limits the health and participation of older people. Rather, it is individual and societal misconceptions, discrimination and abuse that prevent active and dignified ageing." (ONU, 2012)

${ }^{13}$ Para Peixoto (2007, p. 76), são "jovens aposentados", sinônimo de ativos e independentes. Seriam aqueles entre sessenta e setenta e cinco anos de idade.
} 
Das impressões de Bobbio (1997, p. 17-18), ao descrever a sua condição e a dos idosos na Itália, pode-se observar esta diferença:

Hoje um sexagenário está velho apenas no sentido burocrático, porque chegou à idade em que geralmente tem direito a uma pensão. O octogenário, salvo exceções, era considerado um velho decrépito, de quem não valia a pena se ocupar. Hoje, ao contrário, a velhice, não burocrática mas fisiológica, começa quando nos aproximamos dos oitenta, que é afinal a idade média de vida, também em nosso país, um pouco menos para os homens, um pouco mais para as mulheres.

Bobbio, ao escrever a segunda parte dessa sua obra, estava próximo aos oitenta e sete anos. Como o autor trata da questão a partir também de sua experiência pessoal, ele dá a entender que, com o avançar da idade, as pessoas sofrem limitações físicas, tornando-se mais frágeis ${ }^{16} \mathrm{e}$ dependentes ${ }^{17}, \mathrm{e}$, consequentemente, vulneráveis ${ }^{18}$. Assim expõe ele:

A verdade é que - é difícil explicar aos mais jovens - a descida em direção a nenhum lugar é longa, mais longa que eu jamais imaginara, e lenta, a ponto de parecer quase imperceptível (mas não para mim). A descida é contínua e, o que é pior, irreversível: você desce um pequeno degrau de cada vez, mas ao colocar o pé no degrau mais baixo sabe que nunca mais vai retornar ao degrau mais alto. Quantos ainda existem eu não sei. Mas de uma coisa não tenho dúvida: restam cada vez menos. (BOBBIO, 1997, p. 34)

Dessa forma, constata-se que ao atingir a "idade burocrática", os idosos continuam, segundo concluem

\footnotetext{
${ }^{14}$ Segundo Peixoto (2007, p. 76) esta é uma nomenclatura francesa para designar pessoas maiores de setenta e cinco anos. A mesma autora (p. 81) afirma que o Brasil não chegou à quarta idade.

${ }^{15}$ Para Peres (2011, p. 117): "se observa uma alteração na composição etária dentro do próprio grupo, integrado, ele mesmo hoje por uma população 'mais idosa', acima dos 80 anos”.

${ }^{16}$ Segundo Teixeira (2010, p. 13): "Fragilidade é um termo de uso crescente entre os profissionais da Gerontologia e Geriatria para indicar uma síndrome clínica, que torna os idosos vulneráveis ao declínio da capacidade funcional, às quedas, às comorbidades e à redução da expectativa de vida.”. No entanto, a mesma autora concluiu que, para o Brasil, há necessidade de pesquisas sobre este conceito (2010, p. 114-115).

${ }^{17}$ Depreende-se do Livro Branco da Espanha, do Ministério do Trabalho e Assuntos Sociais, no Capítulo I (2004, p. 6) que a evidência empírica disponível mostra que há uma estreita relação entre a dependência e a idade, pois o percentual de indivíduos com limitações em sua capacidade funcional aumenta conforme se consideram grupos de maior idade. Esse aumento nas taxas de prevalência por faixa etária não ocorre em um ritmo constante, mas não há uma idade específica (geralmente em torno de 80 anos) para que este aumento acelere significativamente. Nesse mesmo Livro, conclui-se que existe uma nítida inter-relação entre a saúde e as situações de dependência. No Capítulo XII (2004, p. 4), o Livro conceitua a dependência baseando-se na definição do Conselho da Europa: "aquele estado em que encontram as pessoas que, por razões ligadas a falta ou a perda de autonomia física, psíquica ou intelectual, apresentam necessidade de assistência e/ou de ajudas importantes a fim de realizarem os atos correntes da vida diária.”. Tratando, ainda, que há graus desta dependência. [tradução livre].

Consta no original: "La evidencia empírica disponible muestra que existe una estrecha relación entre dependencia y edad, pues el porcentaje de individuos con limitaciones en su capacidad funcional aumenta conforme consideramos grupos de población de mayor edad. Ese aumento en las tasas de prevalencia por grupos de edad no se produce a un ritmo constante, sino que existe una edad (alrededor de los 80 años) en que dicho aumento se acelera notablemente" (2004, p. 6)

Consta no original: "Se asume como concepto válido de la dependencia la definición del Consejo de Europa aquel estado en que se encuentran las personas que, por razones ligadas a la falta o a la pérdida de autonomía física, psíquica o intelectual, tienen necesidad de asistencia y/o ayudas importantes a fin de realizar los actos corrientes de la vida diaria.".

${ }^{18}$ Para o francês Favier (2013, p. 5), o idoso ou o portador de problemas de saúde, bem como as pessoas fisicamente e psicologicamente fragilizadas e aquelas protegidas pela Seguridade Social [ ... ], têm vocação para ingressar na categoria das pessoas vulneráveis. Deve-se ressaltar que, no âmbito do Direito do Consumidor, o idoso é reconhecido como "hipervulnerável", o que, segundo Schmitt (2009, p. 6) "permitiu a punição, ainda que em pequena escala, representada por casos esparsos, de fornecedores que rescindiram ilegalmente contratos de planos de saúde de consumidores idosos, ou que impuseram elevados reajustes nas prestações destes planos".
} 
Viegas e Gomes (2007, p. 89), a "encenar a vida em sociedade como os restantes seres sociais que a constituem, a não ser na medida em que estão perigosamente na iminência de se destituírem do seu papel de ator para passar ao de espectador".

Desde Roma antiga a questão que envolve o idoso é observada. Da obra "De Senectute”, de Cícero (s.d., p. 65). ${ }^{19}$, na qual o filósofo conclui, a partir de diálogo vivenciado por Catão - o idoso da Sociedade Romana -, que "a velhice, com efeito, é honorável, contando que se defenda a si mesma, que mantenha seus direitos, que não se submeta a ninguém e que até o derradeiro alento guarde seu império sobre os seus”.

Referindo-se ainda à Sociedade Romana e o seu respeito para com o idoso, é interessante transcrever as palavras de Henrique (1935, p. 22):

Os respeitos aos parentes e aos mais velhos fazia parte dos rigores da educação. Depois dos banquetes, os jovens, à imitação do que se fazia em Esparta, eram obrigados a conduzir à casa os velhos, sempre dignos de consideração. A sobriedade e simplicidade que tornaram a velha Roma forte, constituiram um dos fundamentos da educação.

Nesse sentido, explica Wolkmer (2004, p. 7), ao tratar sobre o direito nas sociedades primitivas - "fonte criadora de preceituações jurídicas nas sociedades arcaicas" - certas decisões utilizadas pelos chefes ou anciãos das comunidades autóctones eram utilizadas para resolver conflitos do mesmo tipo. Este fato demonstra o respeito e valor conferidos ao idoso ao longo da história.

Dos clássicos, indispensável mencionar a obra de Platão, "A República", que influenciou os escritos da Antiguidade sobre o envelhecimento, especialmente a obra acima referenciada de Cícero (VIEGAS; GOMES, 2007, p. 27). Platão (1965; p. 69-70) valoriza o idoso ${ }^{20}$ e os defende, como se observa nas palavras de Céfalo:

Alguns se queixam dos ultrajes a que a idade os expõem, por parte de seus próximos e, a este propósito, acusam com veemência a velhice de lhes ser a causa de tantos males. Mas, na minha opinião, Sócrates, não alegam a verdadeira causa, pois, se fosse a velhice, também eu sentiria os seus efeitos, e todos os que chegaram a esta idade. Ora, encontrei outros velhos que não se sentiam assim [...]

A preocupação com o envelhecimento também foi sentida por Descartes ${ }^{21}$ e Bacon, com destaque a obra "Nova Atlântida"22.

\footnotetext{
${ }_{19}$ Obra traduzida e comentada por Tassilo Orpheu Spalding, com o título "Da velhice e da amizade: dois diálogos de Marco Túlio Cícero”, na qual o comentarista esclarece que Cícero se refere, exclusivamente, à velhice do homem público, e que também não se refere às mulheres (s.d., p. 45).

${ }^{20}$ Em seu diálogo com Sócrates, Platão (1965, p. 69) valoriza o idoso, ao expressar, durante a conversa, que Sócrates gosta de conversar com "os velhos". Platão diz que Sócrates acredita que se possa muito saber dos idosos, já que os "velhos" são pessoas que antecederam aos demais, inclusive a ele mesmo e a Sócrates. Sócrates também questiona Céfalo sobre o "limiar da velhice” (expressão tratada por Homero, em Ilíada, XXII, 60, XXIV, 487).

${ }^{21}$ As mortes recentes na família de Descartes tornam-no consciente de sua mortalidade. Descartes também estava atento a seus novos cabelos brancos, aos 47 anos, o que o deixou mais preocupado com o processo de envelhecimento, passando a se interessar pelo estudo do corpo humano e da alma. Desejava saber uma maneira para viver por mais um século, conforme narra Aczel (2005, p. 122).

${ }^{22} \mathrm{Na}$ fábula "Nova Atlântida”, os náufragos doentes são tratados e, sobre o tempo em que estiveram na ilha, em Bensalém, assim narram: "tivemos a cada hora a satisfação de ver melhorarem nossos doentes, que se acreditavam colocados nalguma milagrosa fonte de cura, já que tão bem e tão prontamente se recuperavam.. (BACON, 1984, p. 242). Segundo, Oliveira (2002), ao analisar a
} 
A proteção e a defesa dos direitos do idoso brasileiro devem ser objeto de maior atenção por parte da família ${ }^{23}$, da sociedade e do Estado, uma vez que se calcula que, em 2050, 80\% (oitenta por cento) das pessoas idosas viverão em países que hoje se compõem por habitantes de idades baixas ou médias. Somado aos dados apresentados, torna-se interessante trazer o exposto pelo OMS; segundo este órgão, o Brasil terá uma proporção de idosos maior que a dos Estados Unidos em 2050 (OMS, 2012) ${ }^{24}$.

A OMS prevê, então, que até o ano de 2050 o número de idosos que não podem se defender sozinhos irá quadruplicar nos países em desenvolvimento. Muitos idosos com idade muito avançada perdem a capacidade de viver de forma independente, porque eles têm limitações de mobilidade, fragilidade ou outros problemas físicos ou mentais. Muitos precisam de alguma forma de assistência de longa duração, que pode incluir cuidados domiciliares ou comunitários, e ajuda para a vida cotidiana, reclusão em asilos e estadias prolongadas em hospitais $(\mathrm{OMS}, 2015)^{25}$.

Essa também é a preocupação da ONU (2013, p. 75-76), que em relatório da População Idosa no Mundo em 2013, concluiu que:

O envelhecimento estava começando a ter lugar em muitos países em desenvolvimento que tinham experimentado quedas de fertilidade significativas e, por vezes, muito rápido, principalmente na Ásia e na América Latina. Se as projeções atuais estiverem corretas, o envelhecimento vai se tornar um fenômeno praticamente universal durante o século XXI, embora ele vá progredir com diferente intensidade e velocidade em todos os países e regiões. Esta mudança demográfica global implica desafios fundamentais sociais, econômicos e de desenvolvimento e oportunidades, não menos do que é a prioridade crescente para satisfazer as necessidades dos idosos, permitindo-lhes ter vidas mais longas, mais saudáveis e mais produtivas.

$[\ldots]$

O estudo também destacou algumas das principais consequências sociais e econômicas do

obra de Bacon, diz que 'A narrativa [de Bacon] é interrompida subitamente com o aviso a continuação [da obra] não foi compostá. Entretanto, as primeiras edições da "Nova Atlântida" vinham acompanhadas de uma sugestiva listagem das "Maravilhas naturais", que deixa mais claro quais seriam os limites ampliados do novo reino humano: Prolongar a vida; Restituir a juventude; Retardar o envelhecimento; Curar as doenças consideradas incuráveis; Diminuir a dor; Metamorfose do corpo em outro; Fabricar novas espécies; Tornar os espíritos alegres e colocá-los em boa disposição...".

${ }^{23}$ Camarano, et al. considera a situação do Brasil de forma diferente da apresentada pela OMS: "O Brasil parece ser um caso onde as famílias com idosos estão se organizando não só para cuidar destes, mas, também de membros dependentes." (2011, p. 128) (sic). Apesar disso, rotineiramente, constata-se o abandono, o descaso e a falta de proteção dos direitos dos idosos. Nesse sentido, transcreve-se a notícia recentemente publicada pelo Portal do Envelhecimento, da PUC/SP: "Aposentadoria, empréstimos, violação do direito, família e instituições financeiras são temas que fazem parte do contexto de violência cometida contra a pessoa idosa, de norte a sul do país. Falta uma política de conscientização junto à sociedade, para que o respeito, o cuidado e o cumprimento da lei sejam trabalhados e executados pelas pessoas" (2015).

${ }^{24}$ Extrai-se da página oficial da Organização das Naçoeses Unidas, ao tratar sobre o Envelhecimento e o Ciclo de Vida: "Se calcula que en el año 2050 el $80 \%$ de las personas de edad vivirá en países que hoy se consideran de ingresos bajos o medianos, y algunos como China y el Brasil tendrán una proporción de ancianos mayor que la de los Estados Unidos" (ONU, 2015).

${ }^{25}$ Consta no original: "Se pronostica que de aquí al año 2050 la cantidad de ancianos que no pueden valerse por sí mismos se multiplicará por cuatro en los países en desarrollo. Muchos ancianos de edad muy avanzada pierden la capacidad de vivir independientemente porque padecen limitaciones de la movilidad, fragilidad u otros problemas fisicos o mentales. Muchos necesitan alguna forma de asistencia a largo plazo, que puede consistir en cuidados domiciliarios o comunitarios y ayuda para la vida cotidiana, reclusión en asilos y estadías prolongadas en hospitales". 
envelhecimento. As razões para dar-se suporte à velhice (número de adultos em idade ativa por pessoa) já são baixas nas regiões mais desenvolvidas e em alguns países em desenvolvimento, e deverão continuar a cair nas próximas décadas, com a consequente pressão fiscal sobre o apoio do sistema para idosos. Em uma série de países em desenvolvimento, a pobreza é elevada entre as pessoas mais velhas, às vezes até maior do que a população como um todo, especialmente nos países com cobertura limitada dos sistemas de segurança social. Enquanto as pessoas estão vivendo mais tempo há a prevalência das doenças não transmissíveis e o aumento deficiências relacionadas ao envelhecimento da população, que vai colocar uma pressão ascendente sobre os gastos com saúde nas próximas décadas.

Logo, resta caracterizada a necessidade de proteger e defender os direitos do idoso sob uma perspectiva fraterna e solidária, centro de interesse deste trabalho. Este dever é atribuído à família, à sociedade e ao Estado. Afinal, este é o curso natural da vida, caso não ocorra nenhuma fatalidade: tornar-se idoso. O avançar deste ciclo biológico amplia e intensifica a relação de reciprocidade entre o idoso e a doença, isto é: "esta última acelera a senilidade e a idade avançada predispõe a perturbações patológicas, particularmente aos processos degenerativos que a caracterizam" (BEAUVOIR, 1990, p. 37). Constatação essa que também reforçada pelo médico Élie Metchnikoff ${ }^{26}$, ganhador do prêmio Nobel da Medicina em 1908, em razão de seus estudos sobre o envelhecimento.

Com o aumento do número de idosos no país, conforme dados acima expostos, consequentemente se terá a necessidade de cuidados e atenção na área da saúde, tanto por intermédio do sistema público, quanto do sistema privado ${ }^{27}$. Nesse sentido, escreve Veras (2004, p. 150):

Em paralelo às modificações observadas na pirâmide populacional, doenças próprias do envelhecimento ganham maior expressão no conjunto da sociedade. Um dos resultados desta dinâmica é uma demanda crescente por serviços de saúde mais complexos, especializados e de maior custo, sejam eles públicos ou privados.

Para muito além de uma retórica de proteção meramente formal, o que o idoso efetivamente necessita é da (re)afirmação e da tutela plena de sua dignidade. Afinal desde Cícero (s.d., p. 79) já se tinha a percepção de que: “a velhice que se defende com palavras é miserável", isto é, não bastam textos legais visando à proteção e à defesa dos direitos do idoso, mas atitudes e ações concretas que repercutam positivamente na sua vida.

\footnotetext{
${ }^{26}$ As portuguesas Viegas e Gomes (2007, p.34) explicam que Metchnikoff concebia a velhice como uma condição patológica e crônica. O referido médico, segundo sua bibliografia (2008), laborava no Instituto francês Pasteur e, a partir de 1903, começou a investigar o envelhecimento.

${ }^{27}$ Ressalte-se que tramita no Congresso Nacional (remitido à Câmara dos Deputados, em 11.02.2015), o Projeto de Lei da Câmara (PLC) n. 62/2013, que altera os arts. $3^{\circ}$ e 15 da Lei no 10.741, de $1^{\circ}$ de outubro de 2003, que dispõe sobre o Estatuto do Idoso e dá outras providências, e os arts. $4^{\circ}$ e 10 da Lei no 8.842, de 4 de janeiro de 1994, que dispõe sobre a política nacional do idoso, cria o Conselho Nacional do Idoso e dá outras providências, com o objetivo de fortalecer a participação das organizações representativas dos idosos na formulação, na implementação e na avaliação de políticas e programas de governo, impondo, inclusive, a formação e educação aos profissionais dos SUS na área de saúde da pessoa idosa.
} 


\section{A ATUAÇÃO DO PODER JUDICIÁRIO NA IMPLEMENTAÇÃO DAS POLÍTICAS PÚBLICAS DE SAÚDE ${ }^{28}$}

Este artigo vem apresentado sustentação para a tese de que o Poder Judiciário deve atuar nas questões que envolvem políticas públicas. Há quem afirme que o Judiciário não possui legitimidade para processar e julgar as demandas que envolvem políticas públicas, valendo-se para defender tal argumento, do princípio da separação dos poderes.

A separação das funções estatais/poderes encontra como fundamento, segundo Bodnar (2009, p. 2284), "exatamente a contenção do arbítrio ou abuso estatal em detrimento dos direitos humanos. Assim, quando o Poder Judiciário impõe condutas à Administração Pública é exatamente para que a omissão não lese direitos fundamentais". A tutela da saúde tornou-se um caso exemplar: não há qualquer ilegitimidade na intervenção do Judiciário sobre assuntos referentes à saúde pública. Ao contrário, conforme conclui o referido autor, o controle das omissões injurídicas está respaldado nas razões legitimantes da separação dos poderes estatais.

Todavia, conforme adverte Cittadino (2002, p. 17-42) convém registrar que o processo de judicialização da política não depende de uma atuação paternalista do Poder Judiciário, mas, sobretudo, de uma cidadania juridicamente participativa que pode ser exercida também por intermédio de outros instrumentos de controle social previstos na Constituição.

Freitas (2014, p. 145) reforça a legalidade do Judiciário em controlar a atuação do Estado. Ele expõe que o controle judicial de prioridades constitucionais tem este objetivo, que é "promover decisões políticoadministrativas em consonância com as prioridades da Carta". Não significa, ainda segundo ele, "sobrecarregar o Estado-juiz, vendo-o onipotente e onipresente". Nesse aspecto, o mesmo autor (2014, p. 146) alerta que as políticas públicas:

[...] não devem mais ser vistas como meros programas governamentais mas ou menos livres, ao gosto de eleitos e de seus patrocinadores. São, na realidade, programas constitucionais que incumbem ao agente público implementar, de maneira estilisticamente nuançada, mas sem retrocesso, tampouco omissão específica lesiva.

Cumpre aqui ilustrar, por meio de um exemplo descrito por Freitas (2014, p. 147) para as transgressões inconstitucionais, que "toneladas de remédios são desperdiçadas, enquanto carentes são forçados a judicializar o pleito por medicamentos vitais". Freitas (2014, p. 147) ainda acrescenta que "é tarefa (não exclusiva) do controle judicial, devidamente provocado, cobrar retidão na escolha de prioridades”; e conclui, o referido autor (2014, p.

\footnotetext{
${ }^{28}$ Destaca-se que o Conselho Nacional de Justiça - CNJ, aprovou nova resolução para reduzir a judicialização da saúde, a qual oferece ferramentas para auxiliar o trabalho dos magistrados. Trata-se da Resolução 107/2010, que "criou o Fórum Nacional do Poder Judiciário para a Saúde e instituiu os comitês estaduais de saúde como instâncias adequadas para encaminhar soluções e garantir a melhor forma de prestação jurisdicional em área tão sensível”. BRASIL, Conselho Nacional de Justiça - CNJ. Conselho aprova nova resolução para reduzir judicialização da saúde. Disponível em: <http://www.cnj.jus.br/noticias/cnj/83333-conselhoaprova-nova-resolucao-para-reduzir-judicializacao-da-saude> Acesso em: 15 set. 2016.
} 
156), que o controle judicial das políticas públicas "ostenta o condão de colaborar para desencadear o início do fim do Estado omisso".

Há mais de uma década e meia, Krell (1999) escreveu o artigo intitulado: "Realização dos direitos fundamentais sociais mediante controle judicial da prestação dos serviços públicos básicos (uma visão comparativa)". Neste artigo, o autor afirmou (1999, p. 254) que o sistema jurídico brasileiro já estava "desenvolvendo uma visão do princípio da separação dos poderes" ainda que uma boa parte dos seus operadores não tivesse se dado conta do fato. O mesmo autor ainda ilustrou (1999, p. 252) que:

Em geral, encontramos no Brasil uma resistência ao controle judicial do mérito dos atos do Poder Público, aos quais se reserva um amplo espaço de atuação autônoma, discricionária, em que as decisões do órgão ou do agente público são insindicáveis quanto à sua conveniência e oportunidade. O Supremo Tribunal Federal, na sua atitude exagerada de "auto-restrição judicial" (judicial self-restraint), recusa-se, até hoje, a controlar os pressupostos constitucionais $[\ldots]$ ( sic)

Nesse sentido, Sarlet (2007, p. 12), oito anos depois dessa afirmação, indagava se o Poder Judiciário está autorizado a atender às demandas prestacionais e conferir aos particulares o direito à saúde ${ }^{29}$ :

Permanece, todavia a indagação se o Poder Judiciário está autorizado a atender essas demandas e conceder aos particulares, via ação judicial, o direito à saúde como prestação positiva do Estado, compelindo o Estado ao fornecimento de medicamentos, leitos hospitalares, enfim, toda e qualquer prestação na área da saúde. Na medida em que o nosso poder público não tem logrado atender (e aqui não se está adentrando o mérito das razões invocadas) o compromisso básico com o direito à saúde, constata-se a existência de inúmeras ações judiciais tramitando nos Foros e Tribunais brasileiros, dentre as quais destacam-se as demandas movidas por portadores do HIV na busca do fornecimento dos medicamentos para o tratamento adequado da moléstia e a garantia de uma sobrevida mais longa e com menor sofrimento e, portanto, mais digna.

A realidade atual mudou, e, com o passar do tempo, o Poder Judiciário passou a atuar nos casos que envolvem as políticas públicas de saúde, apesar de se reconhecer que há entendimentos no seguinte sentido:

Esta Corte já firmou jurisprudência sob o fundamento de que não é ônus do Judiciário administrar o SUS, nem se pode, sem conhecimento exato sobre as reais condições dos enfermos, conferir prioridades que só virão em detrimento daqueles pacientes do SUS que já aguardam ou já recebem a medicação e não poderão interromper tratamento. Como os demais enfermos que aguardam o fornecimento do medicamento ou de procedimento cirúrgico pela Administração, deve a parte requerente sujeitar-se à regular dispensação da cirurgia pretendida. Não se pode considerar o Judiciário como uma via que possibilite a um paciente burlar o fornecimento administrativo de medicamentos, garantindo seu tratamento sem que se leve em consideração a existência de outros na mesma ou em piores circunstâncias. (TRF4. Apelação/Reexame Necessário n. 5007457-02.2013.404.7208/SC, Relator Desembargador Luís Alberto D Azevedo Aurvalle, data de julgamento

\footnotetext{
${ }^{29}$ Nesse mesmo artigo, Sarlet (2007, p. 15) destaca a atuação do Supremo Tribunal Federal e a confiança que os demais Tribunais e juízes estavam adquirindo no julgamento de demandas envolvendo o direito à saúde prestacional, "seja pelo fato de não ter cassado, em sede de Reclamação, as decisões proferidas pelos Juízes e Tribunais ordinários, seja por ter considerado, já em mais de um julgamento, que a condenação do Estado no fornecimento de medicamentos, com base em legislação específica, sequer desafia Recurso Extraordinário, já que não se cuida de ofensa direta à Constituição, além de afirmar, recentemente e de modo enfático, o caráter fundamental e, pelo menos em certa medida, também justificável do direito à saúde (na condição de direito subjetivo) no âmbito de nossa ordem jurídico-constitucional".
} 
$19 / 02 / 2014)$

Ou seja, o Poder Judiciário, em alguns casos, tem entendido que não é o seu papel "administrar o SUS"30. Porém, em muitos outros, o Poder Judiciário tem reconhecido a sua legitimidade para tutelar as políticas públicas na área da saúde, conforme se colhe das decisões do Egrégio Supremo Tribunal Federal ${ }^{31}$.

Do julgamento do Recurso Extraordinário com Agravo n. 745.745/MG, Relator Min. Celso de Mello, em 2 de dezembro de 2014 (BRASIL, 2014), depreende-se que o Supremo Tribunal Federal, ao reconhecer a manutenção de rede de assistência a saúde da criança e do adolescente, entendeu pelo desrespeito à constituição provocado por inércia estatal, pela inaplicabilidade da reserva do possível. Segundo ainda o referido julgamento, não deve ser invocada esta cláusula, reserva do possível, quando puder comprometer o núcleo básico que qualifica o mínimo existencial. Nesse mesmo julgamento, os Ministros ratificaram o papel do Poder Judiciário na implementação políticas públicas instituídas pela Constituição da República Federativa do Brasil de 1988 e não efetivadas pelo Estado e expressou sobre os precedentes do Tribunal em tema de implementação de políticas públicas delineadas na referida Constituição.

Do Agravo de Instrumento n. 810.864/RS, julgado em 18 de novembro de 2014, Relator Min. Roberto Barroso (BRASIL, 2014), observa-se que o Supremo Tribunal Federal reconhece que a sua jurisprudência é firme no sentido de que o Estado não pode se eximir do dever de propiciar os meios necessários ao gozo do direito à saúde dos cidadãos. No caso em análise foi decidido pelo fornecimento de fraldas descartáveis a menor portador de doença grave, sob o fundamento de que "o Poder Judiciário pode, sem que fique configurada violação ao princípio da separação dos Poderes, determinar a implementação de políticas públicas nas questões relativas ao direito constitucional à saúde".

Ainda, impende transcrever as palavras do Relator Min. Celso de Mello ao julgar o Recurso Extraordinário com Agravo n. 727.864/PR, em 4 de novembro de 2014 (BRASIL, 2014), que versou sobre o custeio pelo Estado de serviços hospitalares prestados por instituições privadas em benefício de pacientes do SUS atendidos pelo SAMU nos casos de urgência e de inexistência de leitos na rede pública:

Mais do que nunca, é preciso enfatizar que o dever estatal de atribuir efetividade aos direitos fundamentais, de índole social, qualifica-se como expressiva limitação à discricionariedade administrativa.

Isso significa que a intervenção jurisdicional, justificada pela ocorrência de arbitrária recusa

\footnotetext{
${ }^{30}$ Em contraponto a este entendimento, impende registrar um ensinamento de Freitas (2014, p. 157): “O controle judicial terá de se capacitar, a passos largos, para o exame qualitativo de motivações e inferências, pois as políticas públicas só fazem sentido se materializam, com presteza adaptativa, as vinculantes finalidades constitucionais".

${ }^{31}$ Neste caso, pode-se dizer jurisprudência, afinal foi realizada pesquisa para compor este trabalho na página oficial do STF por meio das palavras-chaves: "saúde e políticas e públicas". Dessa busca se extraíram 31 (trinta e um) acórdãos - 1 (um) com repercussão geral. Destes acórdãos, 15 (quinze) versavam diretamente sobre o tema, unânimes quanto ao reconhecimento da atuação do Poder Judiciário na implementação de políticas públicas que envolvem a saúde. Disponível em: <http://www.stf.jus.br/portal/jurisprudencia/listarJurisprudencia.asp?s1=\%28sa\%FAde+e+pol\%EDticas+e+p\%FAblicas\%29\&ba se=baseAcordaos\&url=http://tinyurl.com/oz2lco9>. Acesso em: 10 abr. 2016.
} 
governamental em conferir significação real ao direito à saúde, tornar-se-á plenamente legítima (sem qualquer ofensa, portanto, ao postulado da separação de poderes), sempre que se impuser, nesse processo de ponderação de interesses e de valores em conflito, a necessidade de fazer prevalecer a decisão política fundamental que o legislador constituinte adotou em tema de respeito e de proteção ao direito à saúde.

No mesmo contexto, extrai-se do julgamento do Recurso Especial n. 1.488.639/SE, Relator Min. Herman Benjamin, em 20 de novembro de 2014 (BRASIL, 2014), que o Superior Tribunal de Justiça atua excepcionalmente no controle judicial de políticas públicas e que a sua jurisprudência é consolidada no sentido de reconhecer a legitimidade de qualquer ente federativo integrar no polo passivo da demanda, além de admitir "o bloqueio de verba pública e a fixação de multa diária para o descumprimento de determinação judicial, especialmente nas hipóteses de fornecimento de medicamentos ou tratamento de saúde”.

Do referido julgamento, depreendem-se ainda as seguintes palavras do Relator Min. Herman Benjamin (BRASIL, 2014):

Não podem os direitos sociais ficar condicionados à boa vontade do Administrador, sendo de suma importância que o Judiciário atue como órgão controlador da atividade administrativa. Seria distorção pensar que o princípio da separação dos poderes, originalmente concebido com o escopo de garantia dos direitos fundamentais, pudesse ser utilizado justamente como óbice à realização dos direitos sociais, igualmente relevantes.

Nesse sentido, Sarlet (2015, p. 341-342) conclui que os Tribunais Superiores, com destaque para o Supremo Tribunal Federal "passaram a reconhecer a saúde como direito subjetivo (e fundamental) exigível em Juízo" e afirma que:

Embora o Brasil, juntamente com a Colômbia e alguns outros países, ocupe seguramente uma posição destaque no que diz com o número e a diversidade de ações judiciais na área do direito à saúde e mesmo em termos do número de condenações impostas ao poder público, a assim chamada "judicialização da saúde" representa fenômeno em escala mundial, o que convém seja registrado, ainda que aqui não se possa adentrar o exame de outras experiências nessa seara.

Por fim, interessa a este estudo acrescentar aos fundamentos apresentados a conclusão de Bodnar (2013, p. 304-305) sob a perspectiva de uma gestão séria e comprometida das políticas públicas de saúde por intermédio da atuação do Poder Judiciário:

No controle jurisdicional das políticas públicas sanitárias é fundamental uma visão holística e sistemática da ordem jurídica e do contexto fático da demanda. Essa cautela é relevante para que os objetivos preconizados pela Constituição não sejam entendidos apenas como direitos subjetivos contra o Estado, mas principalmente como uma estratégia coletiva para o alcance da justiça social [...]

$\mathrm{Na}$ perspectiva institucional deve-se também registrar o destacado papel do Ministério Público, principalmente na tutela coletiva do direito fundamental à saúde. A Constituição reconhece a esta instituição importante protagonismo enquanto guardiã dos direitos sociais da coletividade, destacadamente quando atua em prol dos direitos dos idosos em situação de vulnerabilidade e das pessoas com deficiência. 
Assim, resta reconhecida e legítima a atuação do Poder Judiciário no controle das políticas públicas ${ }^{32}$ que envolvem a saúde, quando o Estado - qualquer dos três entes federativos ${ }^{33}$ - é omisso das atribuições constitucionais de proteção e defesa do mínimo existencial, consequentemente de proteção e defesa da dignidade da pessoa humana e mais especificamente da do idoso - interesse maior deste artigo.

Nas crises de descumprimentos das decisões judiciais que outorgam prestações e serviços de saúde, a legislação processual contempla a possibilidade de aplicação de multa, imposição de obrigação de fazer específica e, em situações extremas, inclusive sequestro de valores dos orçamentos públicos.

\section{CONSIDERAÇÕES FINAIS}

Cumpre então ao Poder Público, a gestão e a implementação de políticas públicas de saúde que materializem o direito à saúde. Contudo, quando o Estado é omisso, cumpre ao Poder Judiciário assumir a importante missão de controle das políticas públicas de saúde. Pelo que este artigo demonstrou, tem justamente cabido ao Judiciário por intermédio de suas decisões e na qualidade de guardião dos direitos e garantias fundamentais, resguardar o direito à saúde do idoso para que tal direito não se torne "letra morta na lei".

O idoso, que é considerado a pessoa com idade igual ou superior a sessenta anos, de acordo com o Estatuto do Idoso e com a ONU, é visto muitas vezes pela sociedade como um "fardo" a ser carregado, especialmente na área da saúde pública. Do ponto de vista econômico, o cidadão acima de sessenta anos está inserido em um mercado de consumo e de cultura crescente: lazer, estética e serviços de saúde. Como constatado, não é a idade que limita a saúde e a participação do idoso, mas sim as discriminações e os abusos individuais e sociais.

No entanto, há idosos que não podem se defender sozinhos, ou seja, há aqueles que perderam a

\footnotetext{
${ }^{32}$ Impende registrar que nesta pesquisa não serão abordados os limites deste controle exercido pelo Poder Judiciário. Ilustre-se quanto a esta temática que o STF irá se manifestar no RE n. 684.612/RG, com repercussão geral reconhecida, em 05/06/2015, conforme a seguinte ementa: "ADMINISTRATIVO E CONSTITUCIONAL. IMPLEMENTAÇÃO DE POLÍTICAS PÚBLICAS ESPEFICIAMENTE QUANTO À SUFICIÊNCIA DE PROFISSIONAIS NA ÁREA DE SAÚDE. ALEGADA CONTRARIEDADE AOS ARTS. 2 E 196 DA CONSTITUIÇÃO DA REPÚBLICA. Repercussão geral reconhecida do tema relativo aos limites da competência do Poder Judiciário para determinar obrigações de fazer ao Estado, consistentes em concursos públicos, contratação de servidores e execução de obras que atendam o direito social da saúde, ao qual a Constituição da República garante especial proteção”. (RE 684612 RG, Relator(a): Min. CÁRMEN LÚCIA, julgado em 06/02/2014, PROCESSO ELETRÔNICO DJe-109 DIVULG 05-06-2014 PUBLIC 06-06-2014)

${ }^{33}$ Referente a responsabilidade solidária, recentemente, o STF por unanimidade reconheceu a existência de repercussão geral e por maioria reafirmou a jurisprudência do Tribunal, nos seguintes termos: "RECURSO EXTRAORDINÁRIO. CONSTITUCIONAL E ADMINISTRATIVO. DIREITO À SAÚDE. TRATAMENTO MÉDICO. RESPONSABILIDADE SOLIDÁRIA DOS ENTES FEDERADOS. REPERCUSSÃO GERAL RECONHECIDA. REAFIRMAÇÃO DE JURISPRUDÊNCIA. O tratamento médico adequado aos necessitados se insere no rol dos deveres do Estado, porquanto responsabilidade solidária dos entes federados. O polo passivo pode ser composto por qualquer um deles, isoladamente, ou conjuntamente”. (RE 855.178 RG, Relator(a): Min. LUIZ FUX, julgado em 05/03/2015, PROCESSO ELETRÔNICO DJe-050 DIVULG 13-03-2015 PUBLIC 16-03-2015)
} 
capacidade de viver de forma independente, porque desenvolveram limitações de mobilidade, fragilidade ou outros problemas físicos ou mentais. É exatamente este grupo que até o ano de 2050 irá quadruplicar nos países em desenvolvimento, segundo dados da OMS citados no presente trabalho.

Diante do aumento progressivo no número de idosos, especialmente no Brasil, conforme observado, terse-á ampliada a necessidade de cuidados e atenção na área da saúde, tanto por intermédio do sistema público, quanto por meio do sistema privado. Assim, está caracterizada a necessidade de se proteger, promover, recuperar e defender o direito à saúde do idoso, inclusive por intermédio do Poder Judiciário.

Portanto, na perspectiva do universo observado, tomado no espectro das ações e questões relativas à proteção, promoção, recuperação e defesa voltadas à saúde do idoso, quando submetidas ao Poder Judiciário, conforme examinado no presente artigo, almeja-se que o Poder Judiciário detenha uma atuação cada vez mais sensível e fraterna para com as demandas voltadas às políticas públicas de saúde, especialmente as pertinentes à saúde do idoso.

\title{
THE JUSTICIABILITY PUBLIC POLICIES OF ELDERLY HEALTH
}

\begin{abstract}
The article focuses on the justiciability of public health policies for the elderly. Part of the analysis of the principal for the management and implementation of public health policies; detailing the state of health of the elderly and examines the current position of the Superior Courts as the recognition of their legitimacy to act in the public health policies, especially in cases involving the right to health of the elderly. The research uses the inductive approach method, through the following research techniques: bibliographies, document, cool, and especially through the judicial technique - use of specialized books and magazines.
\end{abstract}

Keywords: justiciability; Public policies; Right to health; Elderly.

\section{REFERENCIAS}

ACZEL, Amir D. O caderno secreto de Descartes: um mistério que envolve filosofia, matemática, história e ciências ocultas. Maria Luiza X. de A. Borges Trad. Rio de Janeiro: Jorge Zahar ed., 2007.233p.

AGUSTINI, Carlos Fernando. A velhice na Constituição brasileira de 1988 como direito fundamental. 2002. Dissertação (Mestrado em Direito) - Universidade Federal de Santa Catarina, Florianópolis.

AITH, Fernando. Curso de Direito Sanitário. São Paulo: Quartier Latin, 2007.

BACON, Francis, Viscount St. Albans, 1561-1626. Nova Altântida. Novum organum ou Verdadeiras indicações acerca da interpretação da natureza; José Aluysio Reis de Andrade Trad. 3 ed. São Paulo: Abril Cultural, 1984. 
BEAUVOIR, Simone de. A velhice. Tradução de Maria Helena Franco Monteiro. Rio de Janeiro: Nova Fronteira, $1990.711 \mathrm{p}$.

BOBBIO, Norberto. O tempo da memória: de senectute e outros escritos autobiográficos. Tradução de Daniela Versiani. Rio de Janeiro: Campus, 1997.205 p.

BODNAR, Zenildo. A (des)judicialização das políticas públicas de saúde na Vara Federal Cível de Criciúma SC. Revista Tempus Actas de Saúde Coletiva. v. 7, n. 1, p. 299-315, 2013. Disponível em: <http://www.tempusactas.unb.br/index.php/tempus/article/view/1298>. Acesso em: 13 nov. 2016.

Controle judicial jurisdicional de políticas públicas ambientais: um desafio qualificado para o Poder Judiciário. In: Anais do XVIII Congresso Nacional do CONPEDI. Florianópolis: Fundação Boiteux, 2009, p. 2275-2288.

BRASIL. Câmara dos Deputados. Projeto Lei n. 62, de 2013, altera os arts. $3^{\circ}$ e 15 da Lei $n^{\circ} 10.741$, de $1^{\circ}$ de outubro de 2003, que dispõe sobre o Estatuto do Idoso e dá outras providências, e os arts. $4^{\circ} \mathrm{e} 10 \mathrm{da}$ Lei $\mathrm{n}^{\circ} 8.842$, de 4 de janeiro de 1994, que dispõe sobre a política nacional do idoso, cria o Conselho Nacional do Idoso e dá outras providências. <http://www.senado.leg.br/atividade/materia/detalhes.asp?p_cod_mate=114300> Acesso em 27 jan. 2017.

Constituição da República Federativa do Brasil de 1988. Disponível em: <http://www.planalto.gov.br/ccivil_03/constituicao/constituicaocompilado.htm>. Acesso em: jun. 2016.

Conselho Nacional de Justiça - CNJ. Conselho aprova nova resolução para reduzir judicialização da saúde. Disponível em: <http://www.cnj.jus.br/noticias/cnj/83333-conselho-aprova-nova-resolucao-parareduzir-judicializacao-da-saude $>$ Acesso em: 15 set. 2016.

Instituto Brasileiro de Geografia e Estatística (IBGE). Sobre a condição de saúde dos idosos: indicadores selecionados.

Disponível

em: <http://www.ibge.gov.br/home/estatistica/populacao/indic_sociosaude/2009/com_sobre.pdf>. Acesso em 26 jun. 2016.

Lei n. 10.741, de 1 de outubro de 2003. Dispõe sobre o Estatuto do Idoso e dá outras providências. Disponível em: <http://www.planalto.gov.br/ccivil_03/leis/2003/110.741.htm>. Acesso em: 18 jul. 2016.

Senado Federal. Projeto Lei n. 219, de 2007, altera a Lei n. 8.080, de 19 de setembro de 1990, para dispor sobre a oferta de procedimentos terapêuticos e a dispensação de medicamentos pelo Sistema Único de Saúde (SUS). Disponível em: <http://www.senado.gov.br/atividade/materia/getPDF.asp?t=51228\&tp=1>. Acesso em: 27 jul. 2016.

Superior Tribunal de Justiça. REsp n. 1.488.639/SE. Relator: Min. Herman Benjamin. Brasilia, 20 de novembro de 2014. Disponível em: <https://ww2.stj.jus.br/processo/revista/inteiroteor/?num_registro=201402691 190\&dt_publicacao=16/12/2 014>. Acesso em: 2 set. 2016.

Supremo Tribunal Federal. AI n. 810.864/RS. Agravo de Instrumento. Relator: Min. Roberto Barroso.

Brasilia, 18 de novembro de 2014.2 Disponível em:
<http://www.stf.jus.br/portal/processo/verProcessoAndamento.asp?incidente=3927828>. Acesso em 22 jul. 2016.

Supremo Tribunal Federal. ARE n. 727.864/PR Recurso Extraordinário com Agravo. Relator: Min. Celso de Mello. Brasilia, 4 de novembro de 2014. Disponível em: <http://www.stf.jus.br/portal/jurisprudencia/listarjurisprudencia.asp?s1=\%28ARE\%24\%2ESCLA\%2E+E+7278 64\%2ENUME\%2E\%29+OU+\%28ARE\%2EACMS\%2E+ADJ2+727864\%2EACMS\%2E\%29\&base=baseAcord aos\&url=http://tinyurl.com/mtvvrm8>. Acesso em 24 jul. 2016.

Supremo Tribunal Federal. ARE n. 745.745/MG. Agravo Regimental no Recurso Extraordinário com Agravo. Relator: Min. Celso de Mello. Brasília, 2 de dezembro de 2014. Disponível em: 
<http://www.stf.jus.br/portal/jurisprudencia/listarJurisprudencia.asp?s1=\%28ARE\%24\%2ESCLA\%2E+E+7457 45\%2ENUME\%2E\%29+OU+\%28ARE\%2EACMS\%2E+ADJ2+745745\%2EACMS\%2E\%29\&base=baseAcord aos\&url=http://tinyurl.com/bpoda2a $>$. Acesso em 23 jul. 2016.

Supremo Tribunal Federal. RE n. 684.612/RJ. Recurso Extraordinário. Relatora: Min. Cármen Lúcia. Brasília, 6 de fevereiro de 2014 . Disponível em: < http://www.stf.jus.br/portal/jurisprudencia/listarJurisprudencia.asp?s1=\%28RE\%24\%2ESCLA\%2E+E+684612 $\% 2 \mathrm{ENUME} \% 2 \mathrm{E} \% 29+\mathrm{OU}+\% 28 \mathrm{RE} \% 2 \mathrm{EPRCR} \% 2 \mathrm{E}+\mathrm{ADJ} 2+684612 \% 2 \mathrm{EPRCR} \% 2 \mathrm{E} \% 29 \&$ base=baseRepercussa o\&url=http://tinyurl.com/ckzuqvm>. Acesso em: 10 jul. 2016.

Supremo Tribunal Federal. RE n. 855.178/SE. Recurso Extraordinário. Relator: Min. Luiz Fux. Brasília, 5

de março de 2015.2 Disponível em:

<http://www.stf.jus.br/portal/jurisprudencia/listarJurisprudencia.asp?s1=\%28RE\%24\%2ESCLA\%2E+E+85517 8\%2ENUME\%2E\%29+OU+\%28RE\%2EPRCR\%2E+ADJ2+855178\%2EPRCR\%2E\%29\&base=baseRepercuss ao\&url=http://tinyurl.com/q6u8omz>. Acesso em 19 jul. 2016.

Tribunal Regional Federal da $4^{a}$ Região. Apelação/Reexame Necessário n. 500745702.2013.404.7208/SC. Relator: Des. Federal Luís Alberto D’Azevedo Aurvalle. Porto Alegre, 19 de fevereiro de $2014 . \quad$ Disponível em: <http://www2.trf4.jus.br/trf4/controlador.php?acao=consulta_processual_resultado_pesquisa\&txtValor=5007 4570220134047208\&selOrigem $=$ TRF \& chkMostrarBaixados $=\&$ todasfases $=S \&$ selForma $=$ NU\&todaspartes $=\&$ hdnRefld=48996dc7935c611c2f5adcaf0deff316\&txtPalavraGerada=DacM\&txtChave=>. Acesso em: 28 jul. 2016.

TRF4, AC 5000378-68.2010.404.7210, Quarta Turma, Relator p/ Acórdão Luís Alberto D'azevedo Aurvalle, D.E. $16 / 11 / 2012$

BUCCI, Maria Paula Dallari (Org.). Políticas Públicas: reflexões sobre o conceito jurídico. São Paulo: Saraiva, 2006. p.31.

CAMARANO, Ana Amélia; et al. Cuidados de longa duração para a população idosa: uma questão de gênero? In. NERI, Anita Liberalesso (Org). Qualidade de vida na velhice: enfoque multidisciplinar. Campinas: Alínea, 2011, p. 127-149.

CÍCERO, MARCO TÚLIO. Da velhice e da amizade: dois diálogos de Marco Tulio Cicero. Introdução, comentário, notas e tradução direta do latim por Tassilo Orpheu Spalding. São Paulo: Cultrix, s. d.c.

CITTADINO, Gisele. Judicialização da política, constitucionalismo democrático e separação de poderes. In: VIANNA, Luiz Werneck (org.). A democracia e os Três Poderes no Brasil. Belo Horizonte: UFMG, Rio de Janeiro: IUPERJ/FAPERJ, 2002.p. 17-42.

COMPARATO, Fábio Konder. Ensaio sobre o juízo de constitucionalidade de políticas públicas. Brasília a. $35 \mathrm{n}$. 138 abr.jun. 1998. Disponível em: <http://www2.senadoleg.br/bdsf/bitstream/handle/id/364/r13804.pdf? sequence $=4>$. Acesso em: 15 jul. 2016, p. 39-48.

CUNHA JÚNIOR, Dirley da. Curso de Direito Constitucional. 4. ed. Salvador: Juspodivm, 2010.

DWORKIN, Ronald. Levando os direitos a sério. Traduzido por Nelson Boeira. São Paulo: Martins Fontes, 2002.

ESPANHA. Ministério do Trabalho e Assuntos Sociais. Atenção as pessoas em situação de dependência na Espanha. Madrid: Livro Branco. 2004, p. 1.022. 
FAVIER, Yann. A inalcançável definição de vulnerabilidade aplicada ao direito: abordagem francesa. Traduzido por Vinicius Aquini e Káren Rick Danilevicz Bertoncello. In: Revista de Direito do Consumidor, v. 85/2013, p. 15, jan./2013.

FREIRE JÚNIOR, Américo Bedê. O controle judicial de políticas públicas. São Paulo: Revista dos Tribunais, 2005.

FREITAS, Juarez. Políticas públicas e controle judicial de prioridades constitucionais. In: Revista da Escola da Magistratura do TRF da 4. Região, vol. I, n. I. Porto Alegre: Tribunal Regional Federal da 4. Região, 2014. p. 141157.

HENRIQUE, João. Roma pagã: suas instituições, usos e costumes. Porto Alegre: Globo, 1935. 241 p.

KRELL, Andreas Joachim. Direitos sociais e controle judicial no Brasil e na Alemanha: os (des) caminhos de um Direito Constitucional "comparado". Porto Alegre: Sergio Antonio Fabris, 2002.

Realização dos direitos fundamentais sociais mediante controle judicial da prestação dos serviços públicos básicos (uma visao comparative). In: Revista de Informação Legislativa, Brasília a. 36 n. 144 out./dez. 1999 p. 239-260. Disponível em: <http://www2.senadoleg.br/bdsf/bitstream/handle/id/545/r14417.PDF? sequence=4>. Acesso em 15 maio 2016.

LOBATO, Alzira Tereza Garcia. Considerações sobre o trabalho do serviço social com idosos. In: A arte de envelhecer: saúde, trabalho, afetividade, Estatuto do Idoso. Aparecida: Ideias \& Letras; Rio de Janeiro: UERJ, 2004.211 p.

MARQUES, Sílvia Badim. O Princípio Constitucional da Integralidade de Assistência à Saúde e o Projeto de Lei 219/07: Interpretação e Aplicabilidade pelo Poder Judiciário. In: Revista de Direito Sanitário. São Paulo, p.1-29, Jul/Out. 2009.

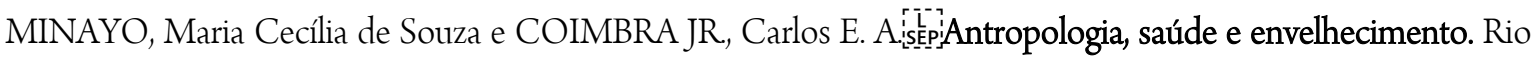
de Janeiro: Editora FIOCRUZ, 2002. 212p. Disponível em: <http://static.scielo.org/scielobooks/d2frp/pdf/minayo-9788575413043.pdfะ. Acesso em 17 jul. 2016.

MODERNO, João Ricardo. Ontoestética do idoso. In: A arte de envelhecer: saúde, trabalho, afetividade, Estatuto do Idoso. Aparecida: Ideias \& Letras; Rio de Janeiro: UERJ, 2004. 211 p.

OMS. Organização Mundial da Saúde. Datos interesantes acerca del envejecimiento. Disponível em: $<$ http://www.who.int/ageing/about/facts/es/>. Acesso em: 18 jul. 2016.

Definition of an older or elderly person. Disponível em: <http://www.who.int/healthinfo/survey/ageingdefnolder/en/>. Acesso em: 18 jul. 2016.

Envejecimiento y ciclo de vida Disponível em:

<http://www.who.int/ageing/about/ageing_life_course/es/>. Acesso em: 18 jul. 2016.

ONU. Declaração Universal dos Direitos Humanos. Disponível em: <http://www.dudh.org.br/wpcontent/uploads/2014/12/dudh.pdf>. Acesso em 26 jun. 2016.

Resolução n. 46/91. Disponível em: <http://www.un.org/documents/ga/res/46/a46r091.htm>. Acesso em: 18 jun. 2016.

A ONU e as pessoas idosas. Disponível em: <http://nacoesunidas.org/acao/pessoas-idosas/ $\geq$. Acesso em: 18 jun. 2016. 
ONU pede saúde adequada a idosos em todo o mundo. Disponível em: $<$ http://nacoesunidas.org/onupede-saude-adequada-a-idosos-em-todo-o-mundo/>. Acesso em: 18 jun. 2016.

Are you ready? What you need to know about ageing. Disponível em: <http://www.who.int/worldhealth-day/2012/toolkit/background/en/index3.html>. Acesso em: 28 jul. 2016.

World Population Ageing 2013. Disponível em: <http://www.un.org/esa/socdev/documents/ageing/Data/WorldPopulationAgeingReport2013.pdf>. Acesso em: 28 jul. 2016.

PEIXOTO, Clarice. Entre o estigma e a compaixão e os termos classificatórios: velho, velhote, idoso, terceira idade... In: Velhice ou terceira idade? Estudos antropológicos sobre identidade, memória e política. Organizado por Myriam Moraes Lins de Barros. Rio de Janeiro: Editora FGV, 2007.236 p.

PERES, Ana Paula Ariston Barion. Proteção aos idosos. Curitiba: Juruá, 2011. 128 p.

PLATÃO. A República. Tradução de J. Guinsburg. São Paulo: Difusão Europeia do Livro, 1965, v. I, 238 p.

SANTA ROSA, Ana Lucia Cardozo de. O envelhecimento na pós-modernidade. In: A arte de envelhecer: saúde, trabalho, afetividade, Estatuto do Idoso. Aparecida: Idéias \& Letras; Rio de Janeiro: UERJ, 2004. 211 p.

SARLET, Ingo Wolfgang. A eficácia dos direitos fundamentais: teoria geral dos direitos fundamentais na perspectiva constitucional. 12 ed. Rev. Atual. e ampl. Porto Alegre: Livraria do Advogado, 2015, 512 p.

Algumas considerações em torno do conteúdo, eficácia e efetividade do direito à saúde na constituição de 1988. Revista Eletrônica sobre a Reforma do Estado (RERE), Salvador, Instituto Brasileiro de Direito Público, n. 11, setembro/outubro/novembro, 2007. Disponível na Internet: <http://www.direitodoestado.com.br/rere.asp>. Acesso em: 27 maio 2016.

SOUZA, C. Políticas Públicas: uma revisão da literatura. In: Sociologias, Porto Alegre, ano 8, n. 16, p. 20-45, $\mathrm{jul} / \mathrm{dez} 2006$.

SOUZA, Edinilsa Ramos de, et al. O idoso sob o olhar do outro. In: MINAYO, Maria Cecília de Souza; COIMBRA JUNIOR, Carlos E. A. Antropologia, saúde e envelhecimento. Rio de Janeiro: Editora FIOCRUZ, 2002. p. 191-209. Disponível em: <http://static.scielo.org/scielobooks/d2frp/pdf/minayo9788575413043.pdf>. Acesso em 17 jul. 2016.

TEIXEIRA, Ilka Nicéia D’Aquino Oliveira. Fragilidade em idosos: conceitos, definições e modelos sob uma perspectiva multidimensional. Londrina: EDUEL, 2010.128 p.

TODOROV. Tzvetan. A vida em comum. Ensaio de antropología geral. São Paulo: UNESP, 2014, 223 p.

VERAS, Renato. Novos desafios contemporâneos no cuidado ao idoso em decorrência da mudança do perfil demográfico da população brasileira. In: A arte de envelhecer: saúde, trabalho, afetividade, Estatuto do Idoso. Aparecida: Ideias \& Letras; Rio de Janeiro: UERJ, 2004.p. 149-174.

VIEGAS, Suzana de Matos; GOMES, Catarina Antunes. A identidade na velhice. Lisboa: AMBAR, 2007. 138 p.

XUN, Wu, RAMESH M., HOWLWTT Michael, FRITZEN, Scott. Guia de políticas públicas: gerenciando processos. Traduzido por Ricardo Avelar de Souza. - Brasília: Enap, 2014. 
WOLKMER, Antonio Carlos. O Direito nas Sociedades Primitivas. In: WOLKMER, Antonio Carlos (org.). Fundamentos de História do Direito. 2 ed. Belo Horizonte: Del Rey, 2004. p. 1-13.

Trabalho enviado em 16 de setembro de 2016.

Aceito em 05 de março de 2017. 